\title{
The Influence of Servant Leadership towards Organizational Commitment: The Mediating Role of Trust in Leaders
}

\author{
See-Kwong Goh ${ }^{1} \&$ Brian Zhen-Jie, Low ${ }^{1}$ \\ ${ }^{1}$ Taylor's Business School, Taylor's University, Malaysia \\ Correspondence: See-Kwong Goh, Taylor's Business School, Taylor's University, Selangor, 47500 Malaysia. \\ Tel: 60-3-562-956-58. E-mail: seekwong.goh@taylors.edu.my or goh.seekwong@gmail.com
}

Received: April 7, 2013

doi:10.5539/ijbm.v9n1p17
Accepted: September 22, $2013 \quad$ Online Published: December 18, 2013

URL: http://dx.doi.org/10.5539/ijbm.v9n1p17

\begin{abstract}
The aim of this paper is to investigate the role of trust in leaders as a mediator between servant leadership style and organizational commitment in the context of market research firms in Malaysia. A total of 177 respondents participated in this survey. A correlation analysis was conducted and the result shows that all variables are significantly correlated at $p<0.01$. In addition, results from the regression analyses indicate that trust in leaders serves as a partial mediator between servant leadership and organizational commitment. Servant leadership and trust in leaders are crucial to maintain higher organizational commitment among employees. Thus, leaders in organization should adopt servant leadership style to gain employees' trust and subsequently employees are more willing to participate and support in organizational activities.
\end{abstract}

Keywords: organization commitment, affective based trust, cognitive based trust, servant leadership

\section{Introduction}

\subsection{Introduce the Problem}

The ideology of "Servant leadership" was first initiated by Robert K. Greenleaf in the 1970s in an essay entitled, The Servant as Leader. Greenleaf concluded that a successful leader has to be a great servant. He believes that this is a crucial trait that leads to the success of a leader. True leadership qualities are developed from those has a deep desire to help others. Furthermore, Greenleaf discussed the need for a better approach to leadership which is one that puts serving others as number one priority. Servant leadership emphasizes increased service to others, a holistic approach to work, promoting a sense of community and the sharing of power in decision making. Since then, Greenleaf's writings on servant leadership have influenced many noted writers, thinkers, and leaders.

In the 21 st century, we witness that many businesses and organizations are shifting from a traditional autocratic and hierarchical mode of leadership towards servant leadership as a way of being in relationship with others. Servant leadership is a model which seeks to involve others in decision-making, is strongly based in ethical and caring behavior and enhances the personal growth of workers while at the same time improving the caring and quality of organizational life (Spears, 2004).

According to Banutu-Gomez (2004) servant leaders elicits trust in followers because they respond to crisis by owning the problem. Thus, when servant leaders put followers' needs and interests above those of themselves by showing concern and empathy for followers, they accumulate the trust of their followers (Banutu-Gomez, 2004). The purpose of this paper is to examine the influence of servant leadership towards trust in leaders. Trust is characterized as affect-based trust and cognitive based trust. The aim of this study is to answer to what extend does servant leadership influence organizational commitment meditated by affect-based trust and cognitive-based trust.

\subsection{Literature Review and Hypotheses}

Servant leadership is defined as a leader's desire to guide and motivate followers as well as to provide a more caring experience through established quality relationship (R. K. Greenleaf \& Spears, 2002). Servant leadership is more than just a leadership style but is about servant hood. It is described as the leader's desire to reach out to the follower who is in need and to serve them wholeheartedly for the sake of followers. To Greenleaf, servant leadership is a leadership concept where the primary function of leadership is to serve others. It is clearly stated 
in his writing "It begins with the natural feeling that one wants to serve, to serve first". Then a conscious choice brings one to aspire to lead. "That person is sharply different from one who is leader first" (R. K. Greenleaf, 1970, p. 13). Greenleaf critically argues that a successful leader has to be a great servant and leadership is about leader that must first and foremost meet the needs of others. Thus, the focus of servant leadership is not upon self but rather on others (R. K. Greenleaf \& Spears, 2002).

In organizational context, the word "leader" is always related to people who have authority and managerial position of giving instruction order to the followers in the organization (Senge, 1990). However, this role of leader is very different to the role of servant leaders whose primary motive is to serve others and to unleash their potential of what they are capable of becoming (R. K. Greenleaf \& Spears, 2002). The focus of servant leader is on the followers instead of organization. Therefore, servant leader highlight the importance of follower's development, holistic needs and autonomy (Graham, 1991). According to Greenleaf, this core value of servant leader supports the followers to develop self-determining, wiser, unrestricted and becoming more like a servant in themselves (R. K. Greenleaf, 1977, p. 13).

Servant leadership sees leadership in a different point of view. It is not about recognition, position, prestige or status. It is not about how to control the followers, but to bring out the full potential of the followers. It is about leaders that will empower their followers by using their position and work alongside with their followers as partners to fulfill organizational objectives. In this study of servant leadership, trust is an essential variable and servant leaders gain the trust of their followers because they respond to crisis by owning the problem and lead with example (Banutu-Gomez, 2004). Subsequently, as when servant leadership elicits greater employees' trust in leaders, it may contribute to improve employees' commitment to the organization (Aryee, Budhwar, \& Chen, 2002).

Trust in leaders: Trust is defined as "the willingness of a party to be vulnerable to the actions of another party based on the expectation that the other will perform a particular action important to the trustor, irrespective of the ability to monitor or control that other party" (Mayer, Davis, \& Schoorman, 1995, p. 712). Trust is also viewed as the level of confidence that one individual has in another's competence and his or her willingness to act in an ethical, fair, and predictable manner (Nyhan \& Marlowe, 1977). In addition, trust is a psychological stated comprising an intention to accept vulnerability based upon positive expectations about the person's behavior (Rousseau, Sitkin, Burt, \& Camerer, 1998).

Trust is a multidimensional construct (Cufaude, 1999; Maren, Wicks \& Huber, 1999) involving two underlying bases which are identified as cognitive trust and affective trust. Cognitive trust and affective trust are the most frequent used distinction in the literature of trust (McAllister, 1995). These two structures and types of trust are differentiated according whether it is rooted in emotion or rationality. Cognitive trust is when individuals look for a rational reason to trust another party, such as ability, responsibility, reliability, dependability, and predictability (Mayer et al., 1995). Likewise, the consistency of the other party's behavior and his or her role of fulfillment might provide a basis for cognitive trust. On the other hand, affective trust refers to the trust that is based on relationship, emotional investment, interactions, and derives more from personal bonds between both parties (McAllister, 1995). Furthermore, affective trust is emphasizing on empathy, rapport, and affiliation on the basis of shared regard for another party.

This study is concerning particularly with trust in leader as we are looking at the leader-followers relationship. When followers trust in their leader, it leads to higher commitment to authorities, increased goal commitment, higher level of job satisfaction, decreased intention to turnover, and improve performance (Dirks \& Ferrin, 2001; McAllister, 1995; E. M. Whitener, Brodt, Korsgaard \& Werner, 1998). Therefore, it is important for followers to trust in their leader. Trust in leader is defined as the willingness of a subordinate to be vulnerable to the actions of his or her supervisor whose behaviors and actions he or she cannot control and whose responsibility is to communicate to them the goals and policies determined by top management (Tan \& Tan, 2000). The central idea of this trust in leader is built on the character of the leader which is focused on how the followers perceive their leader's characters, such as ability, integrity, dependability, and benevolence in the workplace. According to Mayer et al. (1995), all these characters will greatly affect the employees' trust in leaders (Mayer et al., 1995).

Apart from the leader's character, trust in leader is also generated by the leader's behavior, for instance, leader's communicative and supportive behaviors (Tschannen-Moran \& Hoy, 1998). In addition, according to Dirks and Ferrin (2002) leader's care and consideration are also the main factors in building the trust in leader. Hence, it is obvious that a leader's behavior is the medium for accessing on perceptions of trust in leaders (Gardner, Avolio, Luthans, May \& Walumbwa, 2005). In other words, trust in leader is a product of the leader's behavior. Moreover, trust in leader is very important to leadership because it impacts the willingness of follower to accept 
the leader's influence attempts, helps in the establishment of positive relationships, mutual cooperation and open communication between followers and leaders (Zand, 1997).

In this study of servant leadership, trust is an essential variable and there is a significant relationship exists between servant leadership and trust in leader. According to Greenleaf, trust in leader is closely related to servant leadership, in his seminal work, he critically argued that leadership is bestowed upon leaders who are trusted because of their dependability, as they lead with example, empathize with and fully accept followers and most importantly because of their stature as servants (Greenleaf, 1977, p. 24). In servant leadership, servant leaders elicit the follower's trust in leader through the leader's concern that puts the follower's interest as priorities above those of themselves (Farling, Stone, \& Wilston, 1999). Moreover, according to Banutu-Gomez (2004) servant leaders elicits trust in followers because they respond to crisis by owning the problem. Furthermore, because servant leaders lead by setting example, not just talk the talk but walk the walk, empathize with and completely accept their followers, they are able to earn their followers' trust through this kind of servant leader's behavior (Joseph \& Winston, 2005).

Several previous research studies have empirically demonstrated a positive direct effect of servant leadership on trust in leader. The literature reviews that this servant leadership has been particularly considered as strongly related with trust (DePree, 1997; Joseph \& Winston, 2005; Russell, 2001). According to Russell and Stone's (2002) model of servant leadership, the practice of integrity and the way servant leader concern's for people are essential in building follower's trust in leader. Hence, this servant leadership model portraits a strong correlation between servant leadership and trust in leader. Other than Russell and Stone's model of servant leadership, the linkage between servant leadership and trust in leader was also shown in Joseph and Winston (2005) research study of leader in for-profit and not-for profit organizations in America and West Indies. As a result of their study, they reported positive correlation between the employees' perceived level of servant leadership and trust in leader based on the empirical evidence from their research. Based on the justification above, we proposed the following hypotheses:

1a. Servant leadership is positively affecting affect-based trust in leader.

1b. Servant leadership is positively affecting cognitive-based trust in leader.

Organizational Commitment: During the past decades, academicians have been paying much attention on organizational commitment and it has been a subject of many studies (Mathieu \& Zajac, 1990; Mowday, Steers, $\&$ Porter, 1979). The reason for growing interest in organizational commitment is because various previous studies have repeatedly found that organizational commitment is negatively correlated to absenteeism and turnover (Steers, 1975). On the other hand, organizational commitment has been found to be positively associated with job involvement and job satisfaction (Porter, Steers, Mowday, \& Boulian, 1974). Moreover, research has also discovered that higher level of organizational commitment leads to higher level of organizational effectiveness (Arthur, 1994; E. M. Whitener, 2001). Hence, all these findings have indicated organizational commitment as the core factor that determines the positive or negative organizational outcome.

Porter et al. defined organizational commitment as "a strong belief in and acceptance of organizational goals and values; willingness to exert considerable effort on behalf of the organization, and definite desire to maintain organizational membership" (Porter et al., 1974, p. 604). Generally speaking, organizational commitment is described as the employees' attachment with their organization and it is very much correlated to the achievement of long-term organizational goals. When employees are committed to their organization, they are willing to make significant personal contribution, exert additional effort beyond their job description and have a strong desire to continue working for the organization (Allen \& Meyer, 1990). From a more practical point of view, organizational commitment is described as a psychological bond that links an employee to an organization that makes it less likely for employee to leave the organization (Mathieu \& Zajac, 1990).

Today, organizations are striving to achieve higher level of organizational commitment among their employees because it is one of the essential factors that sustain the growth of the organizations. Employees with strong organizational commitment are more compatible, more satisfied and more productive. Furthermore, they will work with more commitment and responsibility, thus they reduce the unnecessary cost for the organization (Bateman \& Strasser, 1984; Suliman, 2002). Besides that, several studies have recognized organizational commitment as a significant factor that influences positive organizational behavior, for instance employee attendance, retention, and their job performance (Mathieu \& Zajac, 1990; Meyer \& Allen, 1997; Randall, 1990).

\subsection{Trust as a Mediator}

According to Zand (1997), when employees trust in their leader, it will increase their relationships, satisfaction 
of their work, and their commitment to the organization. Furthermore, studies also show that when there is a higher level of employees trust in leader, employees are more satisfied with their jobs and have a stronger sense of belongingness in their organization (Aryee et al., 2002). In other words, employees who do not trust in their leader are less likely to remain loyal to the organization. Hence, trust in leader plays an important role on interpersonal relationship, cooperation, and employee's commitment in social institutions and markets (Lewicki, McAllister \& Bies, 1998).

In fact up to today, several previous research studies in various settings indicate that trust in leader has a positive influence on organizational commitment (Albrecht \& Travaglione, 2003; Lau \& Moser, 2008; Nyhan, 1999; Sholihin \& Pike, 2009). Lau and Moser (2008) stated that there is a strong correlation between trust in leader and organizational commitment because how the followers perceive their organization is chiefly based on the actions of their leader. Moreover, Albrecht and Travaglione (2003) investigate the relationship between trust in leader and organizational commitment using a sample of employees from two public-sector organizations. As a result, they found that trust in leader positively affects organizational commitment. Besides that, based on the survey of 600 employees in three public organizations, Nyhan (1999) also found that trust in leader is significantly associated with organizational commitment. Likewise, Sholihin and Pike (2009) conducted a survey to examine the impact of trust in leader on organizational commitment. Using samples of managers from private organizations with head offices in Europe and Africa, they have also found that trust in leader is positively associated with organizational commitment.

In line with the findings above, servant leadership has an indirect relationship towards organizational commitment and the relationship is mediated by trust in leaders. Therefore the second hypothesis is posited as below:

2a. The relationship between servant leadership and organizational commitment is mediated by affect-based trust in leader.

2b. The relationship between servant leadership and organizational commitment is mediated by cognitive-based trust in leader.

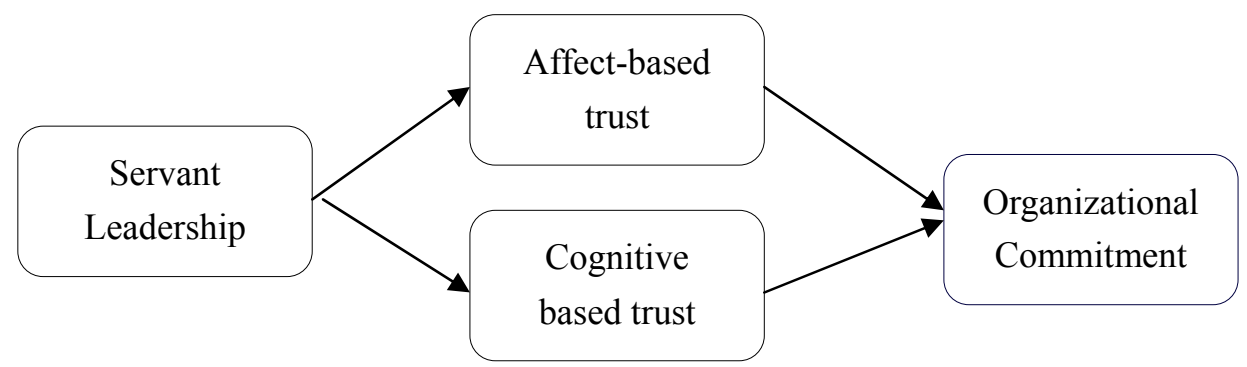

Figure 1. Conceptual model

\section{Method}

A mail survey was conducted to collect data from the respondents in various market research firms in Malaysia. The sampling strategy followed several stages. Firstly, 30 market research firms in Malaysia were selected randomly from the yellow pages and ESOMAR association website. The researchers then contact the targeted firms to seek for their approval. After securing the approval, the survey forms were handed over to the human resource department of each firm. Respondents are given three weeks to distribute and answer the survey questions. At the end of third week, the researchers will collect the survey forms from the respective market research firms. A total of 400 survey invitations were sent to potential respondents; 190 completed surveys were returned. However, only 177 survey forms were usable because 13 were incomplete, hence rendering them unusable for the survey. Therefore, the concluding overall response rate was $44 \%$.

All items for the constructs were adapted from past studies and measured on a 7-point Likert scale; ranging from 1 = extremely disagree, $2=$ strongly disagree, $3=$ disagree, $4=$ neither agree nor disagree, $5=$ agree, $6=$ strongly agree and $7=$ strongly agree. Table 1 list all the constructs, sources and number of items used. 
Table 1. Constructs, item and source

\begin{tabular}{lll}
\hline Variable & Total Items & Source \\
\hline Servant Leadership (SL) & 14 & Ehrhart (2004) \\
Trust in Leader - Affective Trust (AT) & 5 & Yang, Mossholder \& Peng (2009) \\
Trust in Leader - Cognitive Trust (CT) & 5 & \\
Organizational Commitment (OC) & 9 & Mowday et al. (1979) \\
\hline
\end{tabular}

\section{Results}

A Cronbach coefficient alpha test was conducted on all four factors to test the reliability of all of the item variables. This was to determine the internal consistency of the scale used. The values of Cronbach Alpha coefficient are depicted below in Table 2. All of the factors were found to have alpha coefficient values of greater than 0.7, which is an acceptable level of reliability (Hair, Black, Babin, Anderson, \& Tatham, 2006). A closer examination of the mean scores reveals that generally, employees are committed to the organization and has high trust in their leaders. The correlations revealed that all variables are correlated at $p<0.01$. Servant leadership has the strongest correlation towards organizational commitment $(r=0.61, p<0.01)$. It is followed by cognitive based trust $(r=0.60 ; p<0.01)$ and affective based trust $(r=0.56, p<0.01)$. From these results, we can conclude that both $\mathrm{H} 1 \mathrm{a}$ and $\mathrm{H} 1 \mathrm{~b}$ are supported. The strength of the relationships is considered strong.

Table 2. Descriptive statistics, reliabilities, and correlations

\begin{tabular}{|c|c|c|c|c|c|}
\hline & Mean (S.D) & SL & AT & $\mathrm{CT}$ & $\mathrm{OC}$ \\
\hline SL & $\begin{array}{c}4.63 \\
(1.03)\end{array}$ & $(0.872)$ & & & \\
\hline $\mathrm{AT}$ & $\begin{array}{c}4.57 \\
(1.23)\end{array}$ & $.556^{* *}$ & $(0.923)$ & & \\
\hline $\mathrm{CT}$ & $\begin{array}{c}4.91 \\
(1.15)\end{array}$ & $.601^{* *}$ & $.708^{* *}$ & $(0.926)$ & \\
\hline $\mathrm{OC}$ & $\begin{array}{c}4.72 \\
(1.18)\end{array}$ & $.610^{* *}$ & $.656^{* *}$ & $.613^{* *}$ & $(0.948)$ \\
\hline
\end{tabular}

In order to examine $\mathrm{H} 2 \mathrm{a}$ and $\mathrm{H} 2 \mathrm{~b}$ which involves a mediator, multiple linear regression analyses were conducted. Each hypothesis required three linear regression analyses; (i) dependent variable is regressed on the independent variable, (ii) mediator is regressed on the independent variable and. (iii) dependent variable is regressed on both the independent variable and the mediator variable. The mediator variable must be significant for the third regression and the beta coefficient for the independent variable has to be lowered that the first equation (Baron \& Kenny, 1986).

Based on Table 3 below, all regressions are significant and the $\operatorname{Adj}^{2}$ value is the strongest at the third equation where the dependent variable is regressed on both the independent variable and the mediator variable $\left(\right.$ Adj $^{2}=$ 0.511). This indicates that $51.1 \%$ of organizational commitment is explained by servant leadership and affective based trust. Both the independent and mediator variables are significant and the predictive power of SL has decreased from $0.701(p<0.01)$ for regression 1 to $0.408(p<0.01)$ for regression 3. However SL is still significant at regression 3 and this indicates that AT is a partial mediator. Thus, H2a is partially supported. 
Table 3. Multiple linear regression-AT as mediator

\begin{tabular}{llll}
\hline Regression 1: Dependant variable $-\mathrm{OC}$ & & \\
\hline Variable & Beta coefficient & $\mathrm{t}$-stat & $F=103.58^{* *}$ \\
Constant & $1.478^{* *}$ & 4.53 & $R^{2}=0.372$ \\
$\mathrm{SL}$ & $0.701^{* *}$ & 10.18 & Adj $^{2}=0.368$ \\
\hline Regression 2: Dependant variable - AT & & \\
\hline Variable & Beta coefficient & $\mathrm{t}$-stat & $F=78.18^{* *}$ \\
Constant & $1.485^{* *}$ & 4.161 & $R^{2}=0.309$ \\
SL & $0.666^{* *}$ & 8.842 & Adj $^{2}=0.305$ \\
\hline Regression 3: Dependant variable - OC & & \\
\hline Variable & Beta coefficient & $\mathrm{t}$-stat & $R^{2}=0.53 .139^{* *}$ \\
Constant & $0.826^{* *}$ & 2.745 & Adj $^{2}=0.511$ \\
SL & $0.408^{* *}$ & 5.603 & \\
AT & $0.439^{* *}$ & 7.233 & \\
\hline
\end{tabular}

$* * p<0.01,(N=177)$.

Servant Leadership (SL).

Affective based Trust (AT).

Organizational Commitment (OC).

Table 4. Multiple linear regression $-\mathrm{CT}$ as mediator

\begin{tabular}{llll}
\hline \multicolumn{2}{l}{ Regression 1: Dependant variable - OC } & & \\
\hline Variable & Beta coefficient & t-stat & $F=103.58^{* *}$ \\
Constant & $1.478^{* *}$ & 4.53 & $R^{2}=0.372$ \\
SL & $0.701^{* *}$ & 10.18 & Adj $R^{2}=0.368$ \\
\hline Regression 2: Dependant variable - AT & Beta coefficient & t-stat & $F=99.04^{* *}$ \\
\hline Variable & $1.795^{* *}$ & 5.594 & $R^{2}=0.361$ \\
Constant & $0.674^{* *}$ & 9.952 & Adj $R^{2}=0.358$ \\
SL & Beta coefficient & t-stat & \\
\hline Regression 3: Dependant variable - OC & 2.344 & $R^{2}=0.467$ \\
\hline Variable & $0.767^{*}$ & 5.450 & Adj \\
Constant & $0.434^{* *}$ & 5.583 & \\
SL & $0.396^{* *}$ & & \\
AT & &
\end{tabular}

$* p<0.05,{ }^{* *} p<0.01,(N=177)$.

Servant Leadership (SL).

Cognitive based Trust (CT).

Organizational Commitment (OC).

Based on table 4 above, all regressions are significant and the $\operatorname{Adj}^{2}$ value is the strongest at the third equation where the dependent variable is regressed on both the independent variable and the mediator variable $\left(A d j R^{2}=\right.$ 0.461). This indicates that $46.1 \%$ of organizational commitment is explained by servant leadership and cognitive based trust. Both the independent and mediator variables are significant and the predictive power of SL has decreased from $0.701(p<0.01)$ for regression 1 to $0.434(p<0.01)$ for regression 3. However SL is still 
significant at regression 3 and this indicates that $\mathrm{CT}$ is a partial mediator. Thus, $\mathrm{H} 2 \mathrm{~b}$ is partially supported.

\section{Discussion}

Overall, this research provides new finding to the existing literature whereby trust in leaders serves as a partial mediator between servant leadership and organizational commitment.

The result of this study suggests that managers should practice servant leadership. Servant leadership holds an important key to raise trust in leader and organizational commitment among employees. This finding shows that employees have higher trust in leader and higher organizational commitment level when their leader practices servant leadership style of management. This is because the behaviors of servant leadership can be useful particularly for leaders to break down the walls between leader and followers by conveying support for the follower's well-being. Therefore, managers should increase service to others, showing concern and empathy for followers and promoting a sense of community to improve the trust in leader and organizational commitment level in their companies.

This study also implies that managers should not just focus on the conventional top-down form of leadership and hierarchical pyramid. Instead, leaders must assume leadership as a collective way where servant leadership emphasizes a strong involvement between leader and follower and seeking consensus of everyone. By doing so, it creates a positive impact on the employees and it was shown that servant leadership able to enhance the trust in leader and organizational commitment among employees in this study. Additionally, human resources have become one of the important elements to gain competitive advantage in this $21^{\text {st }}$ century. Therefore, in order to stay as a strong organization in this competitive business world, leaders and managers should develop servant leadership style to raise higher organizational commitment among employees for companies to sustain its human resources capabilities.

\section{References}

Albrecht, S., \& Travaglione, A. (2003). Trust in Public-sector Senior Management. The International Journal of Human Resource Management, 14(2), 76-92. http://dx.doi.org/10.1080/09585190210158529

Allen, N. J., \& Meyer, J. P. (1990). The Measurement and Antecedents of Affective, Continuance and Normative Commitment to the Organization. Journal of Occupational Psychology, 63(1), 1-18. http://dx.doi.org/10.1111/j.2044-8325.1990.tb00506.x

Arthur, J. B. (1994). Effects of Human Resource System on Manufacturing Performance and Turnover. Academy of Management Journal, 37(3), 670-687. http://dx.doi.org/10.2307/256705

Aryee, S., Budhwar, P. S., \& Chen, Z. X. (2002). Trust as a mediator of the relationship between organizational justice and work outcomes: test of a social exchange model. Journal of Organizational Behavior, 23(3), 267-285. http://dx.doi.org/ 10.1002/job.138

Banutu-Gomez, M. B. (2004). Great leaders teach exemplary followership and serve as servant leaders. The Journal of the American Academy of Business, 4(1), 143-152.

Baron, R. M., \& Kenny, D. A. (1986). The Moderator-Mediator Variable Distinction in Social Psychological Research: conceptual, strategic, and statistical considerations. Journal of Pesonality and Social Psychology, 51(6), 1173-1182.

Bateman, T. S., \& Strasser, S. (1984). A longitudinal analysis of the antecedents of organizational commitment. Academy of Management Journal, 27(1), 95-96.

Cufaude, J. (1999). Creating organizational trust. Association Management, 51(7), 26-35.

DePree, M. (1997). Leading without Power: Finding Hope in Serving Community. San Francisco, CA: Jossey-Bass.

Dirks, K. T., \& Ferrin, D. L. (2001). The Rrole of Trust in Organisational Settings. Organization Science, 12(4), 450-467. http://dx.doi.org/10.1287/orsc.12.4.450.10640

Ehrhart, M. G. (2004). Leadership and procedural justice climate as antecedents of unit-level organizational $\begin{array}{lllll}\text { citizenship behaviour. } & \text { Personnel }\end{array}$ http://dx.doi.org/10.1111/j.1744-6570.2004.tb02484.x

Farling, M. I., Stone, A., G., \& Wilston, B. (1999). Servant leadership setting the stage for empirical research. Journal of Leadership Studies, 6(1/2), 49-72.

Gardner, W. L., Avolio, B. J., Luthans, F., May, D. R., \& Walumbwa, F. (2005). Can you see the real me? A 
self-based model of authentic leaders and follower development. Leadership Quarterly. 16(3), 343-372.

Graham, J. (1991). Servant-leadership in organizations: inspirational and moral. Leadership Quarterly, 2(2).

Greenleaf, R. K. (1970). The servant as leader. Newton Centre, MA: The Robert K. Greenleaf Center.

Greenleaf, R. K. (1977). Servant Leadership: A Journey into the Nature of Legitimate Power and Greatness. Mahwah, N.J.: Paulist Press.

Greenleaf, R. K., \& Spears, L. C. (2002). Servant Leadership: A Journey into the Nature of Legitimate Power and Greatness. Mahwah, NJ: Paulist Press.

Hair, J. F., Black, W. C., Babin, B. J., Anderson, R. E., \& Tatham, R. L. (2006). Multivariate Data Analysis (2nd ed.). New Jersey: Pearson Prentice Hall.

Joseph, E. E., \& Winston, B. E. (2005). A correlation of servant leadership, leader trust, and organizational trust. Leadership \& Organization Development Journal, 26(1), 6-22. http://dx.doi.org/10.1108/01437730510575552

Lau, C. M., \& Moser, A. (2008). Behavioral Effects of Non-financial Performance Measures: The Role of Procedural Fairness. Behavioral Research in Accounting, 20(2), 55-71.

Lewicki, R. J., McAllister, D. J., \& Bies, R. J. (1998). Trust and Distrust: New Relationships and Realities. The Academy of Management Review, 23(3), 438-458. http://dx.doi.org/10.2307/259288

Maren, R. S., Wicks, A. C., \& Huber, V. L. (1999). Cooperating with the disempowered using ESOPS to forge a stakeholder relationship by anchoring employee trust in workplace participation programs. Business and Society, 38(1), 51-83.

Mathieu, J. E., \& Zajac, D. M. (1990). A Review and Meta-Analysis of the Antecedents, Correlates, and Consequences of Organizational Commitment. Psychological Bulletin, 108(2), 171-194.

Mayer, R. C., Davis, J. H., \& Schoorman, F. D. (1995). An integrative model of organizational trust. Academy of Management Review, 20(3), 709-734.

McAllister, D. J. (1995). Affect- and Cognition-based Trust as Foundations for Interpersonal Cooperation in Organizations. Academy of Management Journal, 38(1), 24-59. http://dx.doi.org/10.2307/256727

Meyer, J. P., \& Allen, N. J. (1997). Commitment in the Workplace: theory, research and application. London: Sage, Thousand Oaks.

Mowday, R. T., Steers, R. M., \& Porter, L. W. (1979). The Measurement of Organizational Commitmen. Journal of Vocational Behavior, 14(2), 224-247.

Nyhan, R. C. (1999). Increasing Affective Organizational Commitment in Public Organizations: The Key Role of Interpersonal Trust. Review of Public Personnel Administration, 19, 58-70.

Nyhan, R. C., \& Marlowe, H. A. (1977). Development and psychometric properties of the organizational trust inventory. Evaluation Review, 21(5), 614-635.

Porter, L. W., Steers, R. M., Mowday, R. T., \& Boulian, P. V. (1974). Organizational Commitment, Job Satisfaction, and Turnover among Psychiatric Technicians. Journal of Applied Psychology, 59(5), 603-609.

Randall, D. M. (1990). The Consequences of Organizational Commitment: Methodological Investigation. Journal of Organizational Behavior, 11(5), 361-378.

Rousseau, D. M., Sitkin, S. B., Burt, R. S., \& Camerer, C. (1998). Not so different after all: Across discipline view of trust. Academy of Management Review, 23(3), 393-404.

Russell, R. F. (2001). The role of values in servant leadership. Leadership \& Organization Development Journal, 22(2), 76-83.

Russell, R. F., \& Stone, A. G. (2002). A review of servant leadership attributes: developing a practical model. The Leadership \& Organization Development Journal, 23(3), 145-157.

Senge, P. M. (1990). The leader's new work: building learning organizations. Sloan Management Review, 32(1), 7-24.

Sholihin, M., \& Pike, R. (2009). Fairness in Performance Evaluation and its Behavioural Consequences. Accounting and Business Research, 39(4), 397-413.

Spears, L. C. (2004). Practicing Servant-Leadership. Leader to Leader, 34, 7-11. http://dx.doi.org/10.1002/lt1.94 
Steers, R. M. (1975). Problems in the Measurement of Organizational Effectiveness. Administrative Science Quarterly, 20(4), 546-558.

Suliman, A. M. T. (2002). Is it really a mediating construct?: The mediating role of organizational commitment in work climate-performance relationship. Journal of Management Development, 21(3), 170-183.

Tan, H., \& Tan, C. (2000). Toward the differentiation of trust in supervisor and trust in organisation. Genetic, Social, and General Psychology Monographs, 126(2), 241-260.

Tschannen-Moran, M., \& Hoy, W. (1998). Trust in schools: A conceptual and empirical analysis. Journal of Educational Administration, 36(4), 334-352.

Whitener, E. M. (2001). Do "High Commitment" Human Resource Practices Affect Employee Commitment? A Cross-Level Analysis Using Hierarchical Linear Modeling. Journal of Management, 27(5), 515-535.

Whitener, E. M., Brodt, S. E., Korsgaard, M. A., \& Werner, J. M. (1998). Managers as initiators of trust: An exchange relationship framework for understanding managerial trustworthy behaviour. Academy of Management Review, 23(3), 513-530.

Yang, J., Mossholder, K. W., \& Peng, T. K. (2009). Supervisory procedural justice effects: The mediating roles of cognitive and affective trust. The Leadership Quarterly, 20(2), 143-154. http://dx.doi.org/10.1016/j.leaqua.2009.01.009

Zand, D. (1997). The leadership triad: Knowledge, trust, and power. New York: Oxford University Press.

\section{Copyrights}

Copyright for this article is retained by the author(s), with first publication rights granted to the journal.

This is an open-access article distributed under the terms and conditions of the Creative Commons Attribution license (http://creativecommons.org/licenses/by/3.0/). 